Journal of Industrial Engineering, Scientific Journal on Research and Application of Industrial System, Vol 5, No. 2, September 2020: 77-88

\title{
Business and Operational Strategy for Service Based Port Company in Indonesia to Face Covid-19 Pandemic
}

\author{
Mohamad Toha, Adi Saptari, and Supriyanto \\ Department of Industrial Engineering. Facultv of Engineering, President University \\ Jl. Ki Hajar Dewantara \\ Kota Jababeka,Cikarang, Bekasi - Indonesia 17550 \\ Email: mohamad.toha@president.ac.id
}

\begin{abstract}
Covid-19 pandemic has threatened the port support service industry in Indonesia. These threats are in the form of decreasing demand throughout the customer market, increasing competition in the industry, rising operating costs, and the emergence of operational issues on how to handle operational activities safely. To deal with these issues, XYZ one of port service company was selected. Primary and secondary data are then collected, SWOT are identified and analyzed and company's business and operational strategies are then formulated. After formulating the business strategy using diamond strategy framework and developing operational strategi based on the business strategy requirement we conclude that the strategies to solve the company problems are strengthening its network, performing taper integration and strengthening operational excellence and customer intimacy simultaneously. The suitable operation strategy to support the above strategies are taper integration, maintaining extemal resources, integrated planning and control, implementation of tight integrated standard business process, and continuous improvement.
\end{abstract}

Keywords: operational strategy, business strategy, Covid-19 pandemic.

\section{ABSTRAK}

Pandemi Covid-19 telah mengancam industri jasa pendukung pelabuhan di Indonesia. Ancaman tersebut berupa menurunnya permintaan di seluruh pasar pelanggan, meningkatnya persaingan di industri, meningkatnya biaya operasional, dan munculnya masalah operasional tentang bagaimana menangani kegiatan operasional secara aman. Untuk mengatasi masalah ini, XYZ salah satu perusahaan jasa pelabuhan dipilih. Data primer dan sekunder kemudian dikumpulkan, SWOT diidentifikasi dan dianalisis serta strategi bisnis dan operasional perusahaan kemudian dirumuskan. Setelah merumuskan strategi bisnis dengan menggunakan kerangka strategi intan dan menyusun strategi operasional berdasarkan kebutuhan strategi bisnis, dapat disimpulkan bahwa strategi untuk menyelesaikan permasalahan perusahaan adalah memperkuat jaringan, melakukan taper integrasi dan memperkuat operasional excellence dan customer intimacy secara bersamaan. Strategi operasi yang sesuai untuk mendukung strategi di atas adalah integrasi taper, pemeliharaan sumber daya eksternal, perencanaan dan pengendalian terintegrasi, penerapan proses bisnis standar terintegras $i$ yang ketat, dan perbaikan berkelanjutan.

Kata kunci: strategi operasional, strategi bisnis, pandemi Covid-19.

\section{Introduction}

\subsection{Background}

During the Covid-19 pandemic in 2020, various companies faced difficult challenge of drastically dedining demand in a very sudden time. Customers reduced outdoor activities, limited interaction between each other and at the same time reduced the consumption of certain services due to feeling threatened by the dangers of this deadly virus. Some industries even stopped their operations to follow the govemment's ban to prevent more widely spread of the Covid-19 vinus. The decline in industrial activity has triggered decreasing demand of energy. Thus, various power plants reduce their operation and automatically reduce their fuel consumption. Port support service companies related to coal transportation are directly affected by this decrease in demand.

One of the companies that experienced in such industry is XYZ. The company is engaged in marine transport support services. The vision of this company is to be a port services company that produce competitive services with global quality standard supported by superior human capital and oriented towards customer satisfaction. 
In 2019, XYZ's business activities included ship loading and unloading, shipping agency, sea freight expedition, tug assist, jetty management, sea transshipment, logistics, dredging, and temporary jetty development

The company was growing very fast in 2015-2019 with its compounded average growth (CAGR) rate of the its sales was around $19,4 \%$. The company also grew its yearly profitability around $20,3 \%$ in the same period. However, the pandemic Covid-19 in 2020 suppress its market demand that impact to its sales with predicted negative growth around $-16 \%$ in 2020.

\subsection{Problem Issues}

The problem that faced by XYZ is actually more than just lowering its sales. There are negative economic trend and lowering customer demand, higher or tougher competition in the industry, and increasing production cost due to higher safety and health requirement to comply with Covid-19 protocols.

\section{a) Economic trend and lowering costumer demand}

During the Covid-19 pandemic, the International Monetary Fund revised down its prediction of global economic growth in 2020. The agency estimates that the world economy would shrink with negative growth of about 4.9\% (Intemational Monetary Fund, 2020) . This negative growth can trigger unemployment, falling incomes, rising poverty, falling asset prices, higher economic inequality, raised govemment borrowing, and increasing number of companies out of business. It means that people buying power would drop to a certain level and automatically the people tend stifle to consume just only their primary needs.

As a part of the world Indonesia suffered with negative economic growth between 0 to $-3 \%$. IMF predicted in October 2020 that it would be $-1,5 \%$. With the average economic growth in 5 years higher than $5 \%$, then shrinking $-1.5 \%$ can be very meaningful. The companies should prepare to change its strategy to overcome the challenged situation.

In the reality, many companies in Indonesia stop their operation when the govemment ban them for several weeks due to the higher rate of infected Covid-19 number. It causes port service provider like XYZ should dedine their activities and even operate below their capacity. Their cost is becoming higher and higher.

\section{b) Lower demand in industrial segment}

During the Covid-19 pandemic the companies, XYZ customers also decreased their activities in accordance with the decreasing their customers' demand. XYZ's austomers even discussed the possibility of some reduction in their coal based fired power plant (PLTU) replaced with biomass fuel. Thus, the customers' demand of port support services could be lower than before. This dedining demand can be temporary or even long-term. If austomers are inspired to use other models to meet their needs, this change will be long-term.

\section{c) Higher competition in the industry and in the segment}

The effect of dedining demand in the industry is tougher competition because the situation is considered like an industry at the dedining stage but the company in it still expects the future (Maylin-Aguilar \& MontoroSanchez, 2020). Competitors in the industry keep in industry and strive to maintain its sales volume to maintain its capacity usage. This situation triggers competition in segments and between segments both healthy competition with prices above its production costs or unhealthy competition with prices below its production costs. If competitors have successfully entered the XYZ market segment then it is possible that they will keep this market segment and will become permanent competitors which could be very dangerous for XYZ future business.

\section{d) Increasing production cost in Covid-19 pandemic era}

The cost of service production becomes more expensive because XYZ has to apply healthy protocol of Covid19 Pandemic by using health equipment and keeping distance (Sjödin, Wilder-Smith, Osm, Farooq, \& Rocklöv, 2020). In addition, the decrease in demand caused the company to operate below its capacity so that the company's fixed cost per unit of service unit is increased.

\section{e) Operational Problems}

Currently, the company does not have standard business processes both to deal with the Covid-19 pandemic and to keep performance fully controlled. With the Covid-19 pandemic, the operators will creatively determine 
their own work methods. This situation leads to unstandardized performance of activities such as effectiveness, maintained health and safety, and efficiency. Thus, controlling service quality, service duration, accident rate and work health and other important performance become more difficult. Without standard operating procedure that completed with its key performance indicators the company also has difficulty to conduct its financial control.

\subsection{Research Objectives}

To solve the above problems this research will focus to three research objectives as follows.

1. To explore extemal and intemal situation of XYZ as impact of Covid-19 pandemic.

2. Formulate business strategy in facing the new situation.

3. Formulate Operational Strategy in accordance with the above strategy.

\section{Methods}

The methodology used in this research can be described as follows:

1. Steps to achieve the research objectives.

The Covid-19 pandemic that pressures on corporate demand suddenly, causes business problems. To solve this business problems, extemal and internal data exploration of the company is carried out. The results of data collection and analysis are summarized into SWOT. Business strategy is formulated based on SWOT using diamond strategy framework (Hembrick \& Fredrickson, 2005) approach and defend strategy concept (Vasconcellos E SA, 2005). Based on this strategy selected altemative operating strategies. The above steps to achieve research objectives are shown in Figure 1.

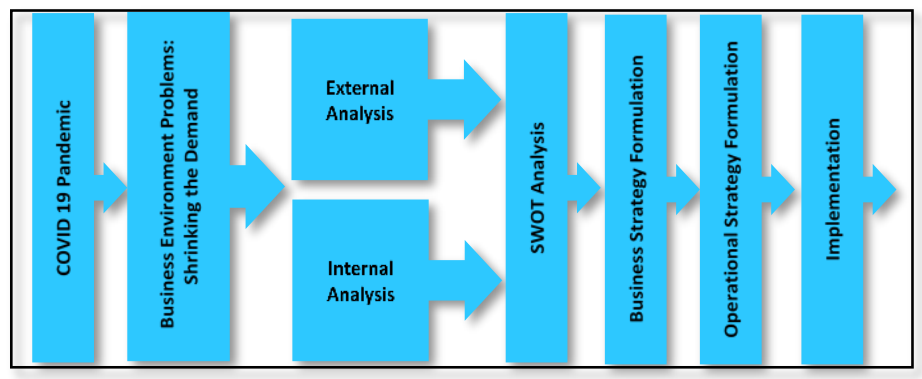

Figure 1 Steps to achieve research objectives

2. Collect company information from its reports and many other resources.

3. Interview with related manager and senior staffs.

4. FGD with related senior managers and senior staffs.

\section{Results and Discussion}

\subsection{Data collection}

\subsection{Business Strategy}

Data collection results indude the company's extemal environmental data, the company's internal condition data and the company's operating practices that explained detail as follows:

\section{a) External Environment}

From interviews and secondary data obtained external environmental data consisting of macro environment and industry environment.

\section{Macro environment}

Macro environment covers political, economic, social, technological, ecological, and legal environment or often called PESTEL. Macro environment is the environment that effect to the company indirectly. However, in Covid19 pandemic case the effects to the industries are significant. It is because of the risk of covid-19 spreading is very high. The industries face severe situations due to the govemment's ban on operation. This situation develops snowball effect back to political, economic, social and legal environment. Ultimately the industry's demand for energy and especially coal is reduced. Thus, the demand for port support services is automatically decreased abruptly. A more complete analysis of PESTEL XYZ is shown in Table 1.

\section{Industry environment}


The declining port service demand is not only occurring in XYZ enterprise environment. Many port service companies are facing steep declining demand so they are operating below capacity. This situation triggered a wave of diversification to gain new markets albeit at prices below what they should be. This movement triggers intense competition that required to get serious attention. To understand the situation in depth, an industry analysis is carried out.

One of the most well-known environmental analyses of the industry is Porter's model of five forces (Porter, 2001). The concept talks that in an industry there are five forces that press the companies' profitability. The five forces are buyers or users, suppliers, competitors, substitutions, and potential entrances. From focused group discussion with management obtained XYZ industrial environment as shown in Figure 2. Figure 2 shows an environmental assessment of the XYZ port services industry.

Table 1 PESTEL Analysis of XYZ

\begin{tabular}{|c|c|c|c|}
\hline nv. & Explanation & $\mathrm{nv}$ & Explanation \\
\hline 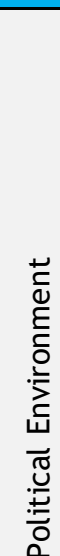 & $\begin{array}{l}\text { With presidential and partiamentary } \\
\text { elections held in Indonesia in 2019, } \\
\text { although there are various differences of } \\
\text { urgency and understanding of the } \\
\text { effectiveness of how Covid-19 is } \\
\text { handled, it is expected that political } \\
\text { stability will persist. }\end{array}$ & 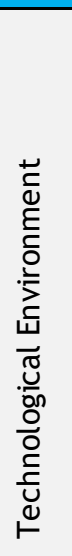 & $\begin{array}{l}\text { Technologlcalchanges, especially Intormation } \\
\text { and communication technology (ICT) have } \\
\text { moved the entire world community into a } \\
\text { fourth industrial revolution with its } \\
\text { destination known as Industry-4.0. In this } \\
\text { industry-4.0 there are four important } \\
\text { advantages used in technology development, } \\
\text { namely (a) data, computing power, and } \\
\text { connectivity, (b) analytics and intelligence, } \\
\text { (c) human-machine interaction, and (d) } \\
\text { digital-to-physical conversion (McKinsey, } \\
\text { 2014). This new technology trend is a good } \\
\text { opportunity for XYZ to improve the } \\
\text { coordination of its scattered operations and at } \\
\text { the same time to improve efficiency and } \\
\text { effectiveness of its working methods. }\end{array}$ \\
\hline 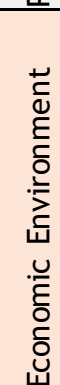 & $\begin{array}{l}\text { Indonesia's economy will stagnate with } \\
0 \% \text { growth (World Bank, 2020) or even } \\
\text { shrink of around -1\% (ADB, 2000) but it } \\
\text { will grow again in } 2021 \text { by } 4.8 \% \text { (World } \\
\text { Bank, 2020). The shrinking economy will } \\
\text { almost certainly lower the XYZ's income } \\
\text { of port services, however the new } \\
\text { growth has not guaranteed that will } \\
\text { recover the business. }\end{array}$ & 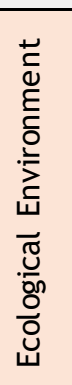 & $\begin{array}{l}\text { The world's pressure to create } \\
\text { environmentally friendly energy will be } \\
\text { stronger in the future due to the adverse } \\
\text { effects of environmental damage caused by } \\
\text { the pollution of waste processes in the formof } \\
\text { CO2, SOx, NOx, and other harmful compounds } \\
\text { from fossil fuel-based plants. Energy sources } \\
\text { in Indonesia today are still dominated by } \\
\text { technology that uses fossil fuels. The situation } \\
\text { suggests that company needs to consider } \\
\text { preparing for a long-term decline in demand }\end{array}$ \\
\hline 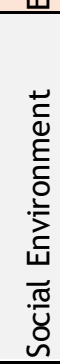 & $\begin{array}{l}\text { Over the past five years there has been } \\
\text { a demographic shift with a growing } \\
\text { number of middle-income communities. } \\
\text { With Covid-19 it is estimated that } \\
\text { middle-income people are falling back } \\
\text { and poverty is rising again. It is expected } \\
\text { that the demand of electricity, the } \\
\text { demand of coal and of course the } \\
\text { demand port services for coal will } \\
\text { decrease. }\end{array}$ & 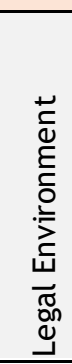 & $\begin{array}{l}\text { Public awareness of the law is getting better. } \\
\text { With the easier access to information as a } \\
\text { result of technological developments, the } \\
\text { impact of public awareness of the right as a } \\
\text { member of society increases. Therefore, the } \\
\text { legal aspect in the business world needs to get } \\
\text { more proportionate attention. }\end{array}$ \\
\hline
\end{tabular}




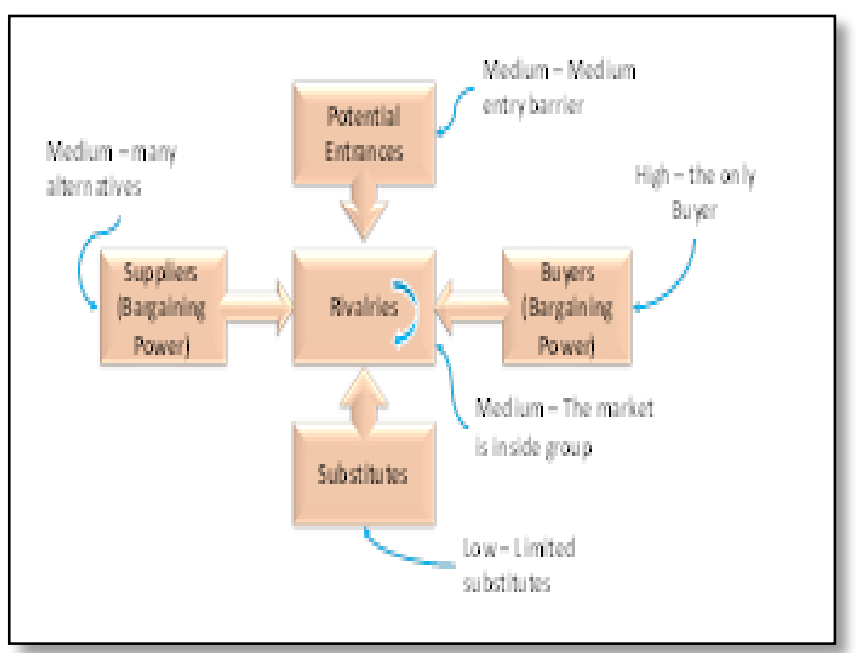

Figure 2 XYZ industrial environment analysis using Porter's Five Forces (Modifies from Porter (2001) for XYZ)

This image shows briefly that the companies in the industry are facing a strong threat of buyer, a medium threat of suppliers, a medium threat of rivals, a medium threat of potential entrances, and a low threat of substitution for services. The reasons for setting the threat level are shown in Table $\mathbf{2}$ as follows:

Table 2 Analysis Five Forces for XYZ Industry

\begin{tabular}{llll}
\hline & Forces & Analysis & $\begin{array}{l}\text { Level of } \\
\text { Forces }\end{array}$ \\
\hline 1 & Customers & $\begin{array}{l}\text { There are only a group of related buyers below Sate Electricity Company } \\
\text { (PLN). }\end{array}$ & High \\
\hline 2 & Suppliers & $\begin{array}{l}\text { Even though it is not very easy to find but there are several supplier } \\
\text { alternatives. }\end{array}$ & Medium \\
\hline 3 & Competitors & The market is a special segment i.e. a group whereXYZ belongs & Medium \\
\hline 4 & Potential Entrance & The entry barrier is high & Medium \\
\hline 5 & Substitutes & No substitution until today & Low \\
\hline
\end{tabular}

b) Internal Condition

XYZ intermal condition is identified based on value-chain concept and assessed using a resource-based view (RBV) approach

- Resources and capabilities

This research uses Porter's concept of value chain (Porter, 1985) to identify resources, however because that is no material to be addressed then logistics activities are eliminated. To handle all resource gathering activities and preparing service govemance a service preparation activity is induded. Thus the primary activities in the XYZ value chain consist of service preparation, service delivery, marketing and sales, and service follow-up.

- VRI framework

Valuable, rare, inimitable and organization or VRIO in Resource-based View (RBV) is an evaluation tool that is believed to predict competitive advantage.

But further studies show only valuable, rare and inimitable quality resources that produce capabilities while organizations are the order that makes VRI a competitive advantage (Cardeal \& Antonio, 2012). The resource analysts are then shown in Table 3. 
Based on the above collected data, PESTEL analysis, Five Forces Analysis, and VRI Analysis obtained company's strengths, weaknesses, opportunities and threats (SWOT). The strengths and weaknesses ere explored from Table 4 and the opportunities and threats are explored from PESTEL analysis and five forces analysis. The results are listed in Table 4.

Table 3 VRI Analysis

\begin{tabular}{|c|c|c|c|c|c|c|c|}
\hline No. & Value Chain & Description & V & $\mathbf{R}$ & $\mathbf{I}$ & CA & $S, M, W$ \\
\hline \multirow{5}{*}{1} & \multirow{5}{*}{ Service Preparation } & Infrastructures & Yes & No & No & $\mathrm{T}$ & W \\
\hline & & Branch Offices & Yes & Yes & No & $\mathrm{T}$ & $\mathrm{S}$ \\
\hline & & Human Resources & Yes & NO & NO & $T$ & $M$ \\
\hline & & Assets & Yes & No & No & $T$ & $\mathrm{~S}$ \\
\hline & & TCT for Monitoring & Yes & Yes & No & $T$ & W \\
\hline \multirow{3}{*}{2} & \multirow{3}{*}{ Service Delivery } & Track Record/Image & Yes & Yes & Yes & $\mathrm{S}$ & St \\
\hline & & Experience & Yes & Yes & Yes & $\mathrm{S}$ & $S$ \\
\hline & & Coordination & Yes & Yes & No & $\mathrm{T}$ & $M$ \\
\hline \multirow{3}{*}{3} & \multirow{3}{*}{ Marketing and Sales } & Relationship with Customers & Yes & No & No & $\mathrm{T}$ & $\mathrm{S}$ \\
\hline & & Proactivty and responsiveness & Yes & Yes & Yes & 5 & $M$ \\
\hline & & Number of Human Resources & Yes & No & No & $T$ & W \\
\hline 4 & Service Follow-up & Manage Customer Satisfaction & Yes & No & No & $T$ & $M$ \\
\hline 5 & Purchasing & Heavy Equipment Licensing & Yes & No & No & $\mathrm{T}$ & $M$ \\
\hline \multirow[t]{2}{*}{6} & $\begin{array}{l}\text { Human Resource } \\
\text { Management }\end{array}$ & Reward System & Yes & Yes & Yes & $\mathrm{S}$ & $M$ \\
\hline & $\begin{array}{l}\text { Technology } \\
\text { Development }\end{array}$ & Investment of Hi-Tech Equipment & Yes & No & No & $\mathrm{T}$ & W \\
\hline 8 & Firm Infrastructure & Heavy Equipment Ownership & Yes & No & No & $\mathrm{T}$ & W \\
\hline
\end{tabular}

Notes: $\mathrm{V}$ - valuable; $\mathrm{R}=$ Rare, $\mathrm{I}$ = in-imitable, Comp. Adv = competitive advantage, $\mathrm{T}$ = temporary, $\mathrm{S}$ - sustainable, $\mathrm{W}$ - weak, $M$ = Medium, $\mathrm{S}$ = strong

Table 4 SWOT of the company

\begin{tabular}{|c|c|c|c|c|c|c|c|}
\hline \multicolumn{2}{|c|}{ Strengths } & \multicolumn{2}{|c|}{ Weaknesses } & \multicolumn{2}{|c|}{ Opportunities } & \multicolumn{2}{|c|}{ Threats } \\
\hline 1 & $\begin{array}{l}\text { Experiences in the } \\
\text { field of port } \\
\text { services, }\end{array}$ & 1 & $\begin{array}{l}\text { Limited } \\
\text { competent human } \\
\text { resources }\end{array}$ & 1 & $\begin{array}{l}\text { Still many } \\
\text { customer's power } \\
\text { plants that can be } \\
\text { served, }\end{array}$ & 1 & $\begin{array}{l}\text { Declining } \\
\text { demand due } \\
\text { to the COVID- } \\
19 \text { pandemic, }\end{array}$ \\
\hline 2 & $\begin{array}{l}\text { High asset } \\
\text { productivity }\end{array}$ & 2 & $\begin{array}{l}\text { Limited hi-tech heawy } \\
\text { equipment ownership }\end{array}$ & 2 & $\begin{array}{l}\text { Still many dredging and } \\
\text { temporary jetty needs, }\end{array}$ & 2 & $\begin{array}{l}\text { Decreased use ot } \\
\text { coal for power } \\
\text { plants }\end{array}$ \\
\hline 3 & $\begin{array}{l}\text { Branch ownership } \\
\text { spread across } \\
\text { Indonesia, }\end{array}$ & 3 & $\begin{array}{l}\text { Inappropriate } \\
\text { business process and } \\
\text { risk management } \\
\text { standard }\end{array}$ & 3 & $\begin{array}{l}\text { New infrastructure } \\
\text { technology }\end{array}$ & 3 & $\begin{array}{l}\text { Tncreasing } \\
\text { potential for new } \\
\text { competitors in } \\
\text { the customer } \\
\text { segment, and }\end{array}$ \\
\hline 4 & Good track record & 4 & Poor control systems & 4 & $\begin{array}{l}\text { The emergence of the } \\
\text { needs for biomass } \\
\text { transportation services } \\
\text { as a new fuel }\end{array}$ & 4 & $\begin{array}{l}\text { The length of the } \\
\text { payment process } \\
\text { from consumers }\end{array}$ \\
\hline 5 & $\begin{array}{l}\text { Strong network to } \\
\text { customers port } \\
\text { service licence } \\
\text { (BUP) ownership. }\end{array}$ & 5 & $\begin{array}{l}\text { Limited ICT support } \\
\text { for management }\end{array}$ & & & 5 & $\begin{array}{l}\text { Covid-19 } \\
\text { increases } \\
\text { companies' } \\
\text { operational cost }\end{array}$ \\
\hline
\end{tabular}

\subsection{Business Strategy}

Developing XYZ business strategy can be done by using the SWOT derivative matrix or TOWS matrix or using other approaches. Strategy development with the TOWS matrix can be obtained a comprehensive strategy but it is a bit difficult to get focus. Because focus becomes very important for companies that are not very large then here used the Hembrick \& Frederickson's diamond framework (Hembrick \& Fredrickson, 2005). The preparation of the strategy begins with the determination of strategic positions, then parsed by inserting them into the diamond framework. 


\section{a) Strategic positioning}

There are three alternatives of disciplines of market leader the company can pursue to be the market leader in industry (Treacy \& Fred, 1996; Verweire, 2018). They are operational excellent, customer intimacy and technology leadership. To select the most favorable for the company it uses multi criteria decision making as shown in Table 5 .

In accordance with the calculation in Table 5 it is concluded that the company will get more opportunities to success during COVD-19 pandemic if the company builds operational excellent and/or customer intimacy. Applying both is better however it is not easy. The company must build two different practice or even culture simultaneously. For operation excellence culture of control is suggested, while for customer intimacy culture of collaboration is suggested. Therefore, all that can be done is to continue to implement a culture of control and build austomer intimacy by applying standards of behavior.

Table $5 \mathrm{XYZ}$ strategic position selection

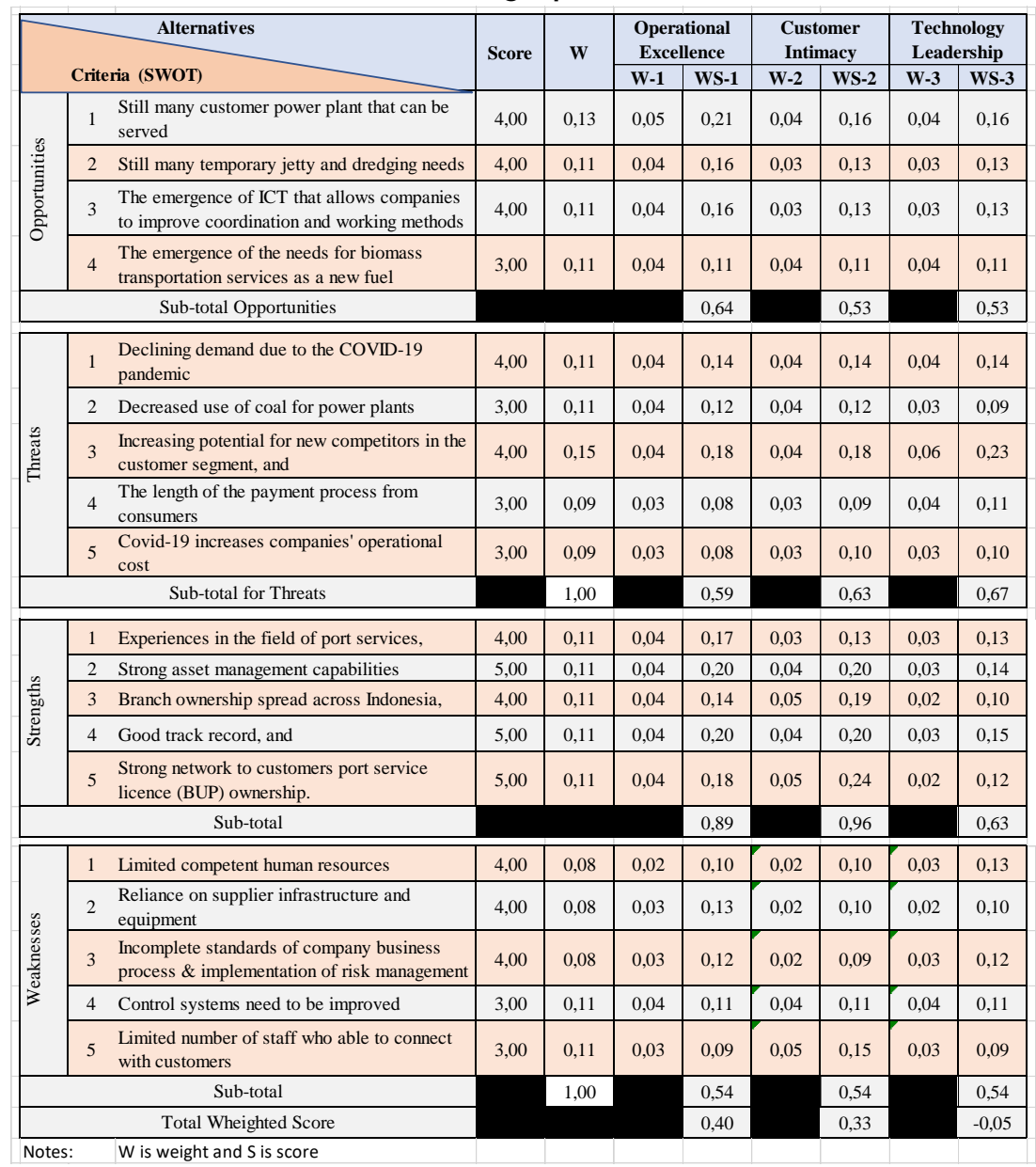

According to the above result of calculation the strategic positioning XYZ is selected aa combination of operational excellence and customer intimacy. The difficulties of integrating two practices is solved by strengthening operational excellence first, setting standard business processes and educating employees to be disciplined. After it is settled the austomer intimacy is developed on the basis of the compliance towards developed basic standard behavior and discipline to apply. Thus, the cultural base is still the same as for operation excellence.

\section{b) Business strategy}

Based on the above strategic positioning the business strategy is formulated by setting arenas, vehicles, differentiators, staging and economic logic as follows.

- $\quad$ Arena 
With the size of the existing market, $X Y Z$ is expected to focus on the existing market by expanding the type of similar services that become the mainstay of the company. Thus, the expansion is by expanding the territory for the same customers with similar services.

\section{- Vehicles}

Vehicle is about how to achieve our arena. It is a vehicle used for strategy to be implicated. XYZ has a considerable annual profit and current assets that are still in the form of account receivables. If the company can accelerate biling and delay payments to customers then this current asset can be utilized to support the company's strategy of building strength.

\section{- $\quad$ Differentiators}

To understand differentiators that effectively attract customers it is necessary to understand the customer. From the results of FGD obtained some of the needs and desires of customers the most important are:

1. Quality of service.

2. Timeliness

3. Low prices

4. Flexible to meet customer expectations

5. Proactively set up and care for customers

6. Implementation of occupational safety and health.

Each differentiator and how XYZ sets it up is shown in Table 6.

Table 6 Customer expectation

\begin{tabular}{lll}
\hline Customer Expectation & Description & $\begin{array}{l}\text { What should the company } \\
\text { have? }\end{array}$ \\
\hline Quality service & No damage or irregularities, fast service & $\begin{array}{l}\text { SOP, trained worker, } \\
\text { certification, sla, } \\
\text { improvement targets }\end{array}$ \\
\hline On time & On time as planned & $\begin{array}{l}\text { SOP, trained worker, } \\
\text { certification, SLA }\end{array}$ \\
\hline Low cost & $\begin{array}{l}\text { Efficient, no cost spike, right supplier } \\
\text { choice. }\end{array}$ & $\begin{array}{l}\text { SOP, trained worker, } \\
\text { certification, cost } \\
\text { effectiveness investment, } \\
\text { improvement targets }\end{array}$ \\
\hline $\begin{array}{l}\text { Flexible to meet customer's } \\
\text { wishes }\end{array}$ & $\begin{array}{l}\text { The schedule can be changed without loss, } \\
\text { all risks have been carefully accounted for. }\end{array}$ & $\begin{array}{l}\text { Proactive planning, risk } \\
\text { management, flexible } \\
\text { people, advance calculation }\end{array}$ \\
\hline $\begin{array}{l}\text { Proactively approach and } \\
\text { address customer concerns }\end{array}$ & $\begin{array}{l}\text { The schedule can be changed without loss, } \\
\text { all risks have been carefully accounted for. }\end{array}$ & $\begin{array}{l}\text { Care, proactive, } \\
\text { management of change, risk } \\
\text { management }\end{array}$ \\
\hline $\begin{array}{l}\text { Occupational safety } \\
\text { health }\end{array}$ & and & Workers are selected and have certificates. \\
\hline
\end{tabular}

\section{- $\quad$ Staging}

Covid-19 pandemic attacks so suddenly require rapid movement. So XYZ needs to conduct quick changes to master the arena in a fast time and at the same time not give competitors a chance to master the arena. Stages of changing of the company characteristics can be explained deeper in strategic roadmaps.

\section{- Economic Logic}

The Company will be able to maintain the cost low using the tight procedures. The tight procedure also keeps the cost stable and predictable. Using care and proactive the company can keep the customers just deliver order to the company or use the company service and price as the main consideration to select the provider. 
There are some important facts for the company that (1) there are many other players in the same industry in different segments, (2) switching segments is not too difficult for the company in the same industry, (3) demand in the field of port services decreases making the players work below their capacity. With these three facts it can be predicted that the competitors will eamestly attempt to enter the XYZ segment; The company needs to prepare for defensive strategies in a variety of ways. There are various altematives of defense strategy (Vasconcellos E SA, 2005) induding signaling, creating entry barrier, global services, pre-emptive strike, blocking, counter attack, holding the ground, and withdrawal. This altemative sequence indicates the size of the risk. The earlier risk is the least. We recommend that companies choose from the earliest order because the risk is the smallest. But signaling doesn't seem effective enough considering the company is still not very big and its voice is not yet heard enough by competitors. Therefore, the second option creates an entry barrier and the third global service seems to be more effective. To build entry barriers the company reforms its technology, builds customer loyalty, builds dose relationships with suppliers, utilizes experience to improve service quality and cost. The company and its parent company also implement global services to cover all port services required by customers. Companies with parent companies need to design integrated services that make it easier for customers to take advantage of them.

- $\quad$ Strategic Roadmaps

To realize the strategy consistently compiled the company's roadmap in five years as shown in Figure 3.

\begin{tabular}{|c|c|c|}
\hline \multirow{4}{*}{ Arena } & 2020 & 2023 \\
\hline & \multicolumn{2}{|c|}{ Existing Market Segment $=$ More location } \\
\hline & \multicolumn{2}{|l|}{ Existing Services } \\
\hline & \multicolumn{2}{|r|}{ New Services } \\
\hline \multirow{6}{*}{$\begin{array}{l}\text { Different } \\
\text { iators }\end{array}$} & Quality service & Quality service \\
\hline & On time & Fast and On time \\
\hline & Low cost & Low cost \\
\hline & Occupational safety and health & Occupational safety and health \\
\hline & Customer Connection & Flexible to meet customer's wishes \\
\hline & & Proactively approach and address customer concerns \\
\hline \multirow{4}{*}{$\begin{array}{l}\text { Vehicl } \\
\text { es }\end{array}$} & \multicolumn{2}{|c|}{ Operational Excellence set-up and continuous improvement } \\
\hline & \multicolumn{2}{|l|}{ Partnership } \\
\hline & Part of Customer Intimacy & Customer Intimacy \\
\hline & & New ICT Implementation \\
\hline \multirow{4}{*}{ Staging } & $\begin{array}{c}\text { Process } \\
\text { Standardization }\end{array}$ & Continuous Improvement \\
\hline & \multicolumn{2}{|c|}{ Training and Implementation } \\
\hline & \multirow[t]{2}{*}{ Behaviour Design } & Improvement \\
\hline & & Training and Implementation \\
\hline $\begin{array}{l}\text { Economic } \\
\text { Logic }\end{array}$ & \multicolumn{2}{|c|}{$\begin{array}{l}\text { The company can do it because it has experiences } \\
\qquad \text { Customers will buv, because thev can get the service that thev want }\end{array}$} \\
\hline
\end{tabular}

Figure 3 Roadmap to win in Covid-19 pandemic (Modified from Hembrick \& Frederickson concept (Hembrick \& Fredrickson, 2005)) 


\subsection{Operational Strategy}

To develop an operation strategy, an understanding of the company's vision and mission (Gupta, Czemik, \& Sharma, 2001) and business strategy is needed. The company's vision is to become a company in the field of port services, which has superior quality to comply with global standards, supported by competent human resources and oriented towards customer satisfaction.

The companys mission is to provide integrated port business services and provide added value for shareholders". Business strategy in the covid-19 pandemic is oriented towards operational excellence and customer intimacy. This means that the company pursues standard quality with low prices and flexibility that are able to serve customers that often change.

To set strategies based on operational excellence and customer intimacy in the pandemic period, operational strategies are developed that include heavy equipment ownership strategies, planning and control strategies, implementation of standard operating procedures, supplier asset utilization strategies.

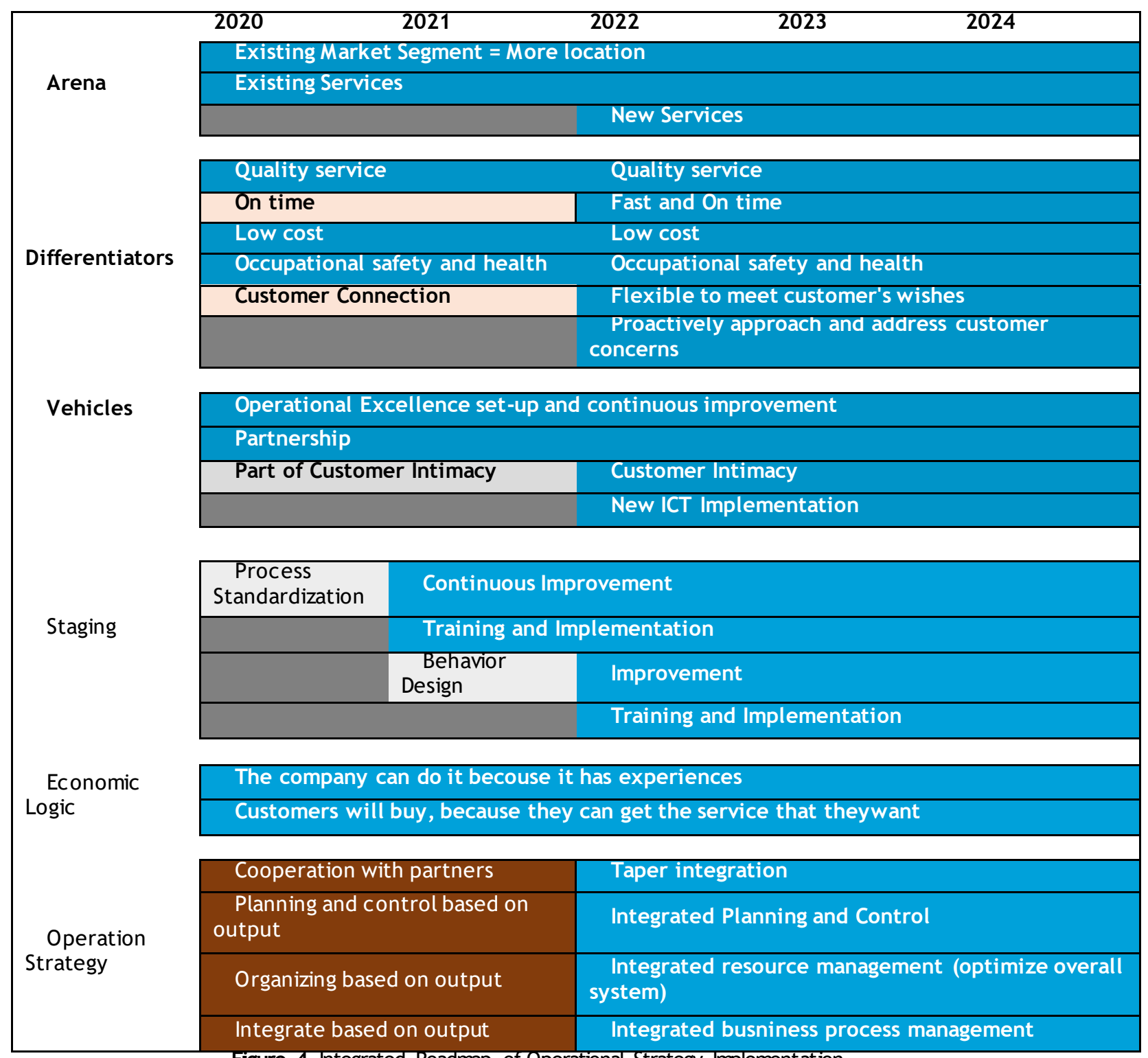

Figure 4. Integrated Roadmap of Operational Strategy Implementation

\section{a) Heavy equipment ownership strategy}

Today XYZ still uses heavy equipment with leases from its suppliers. The intended is to reduce the risk of uncertain ups and downs in consumer demand. With the implementation of operational excellence and austomer intimacy the company needs to review this strategy. There are three alternatives to solve the above 
problems. First the company invests by purchasing all heavy equipment; second the company does taper integration by purchasing a small number of heavy equipment to understand the suppliers and at the same time increase its bargaining power to suppliers; and third the company continues to rent the heavy equipment as it is today.

Based on the assessment of table 4 then the taper integration option is the best choice. The Company can still regulate its suppliers while the company does not have to own all the assets that reduces it flexibility.

Table 7. Selecting Heavy Equipment Ownership

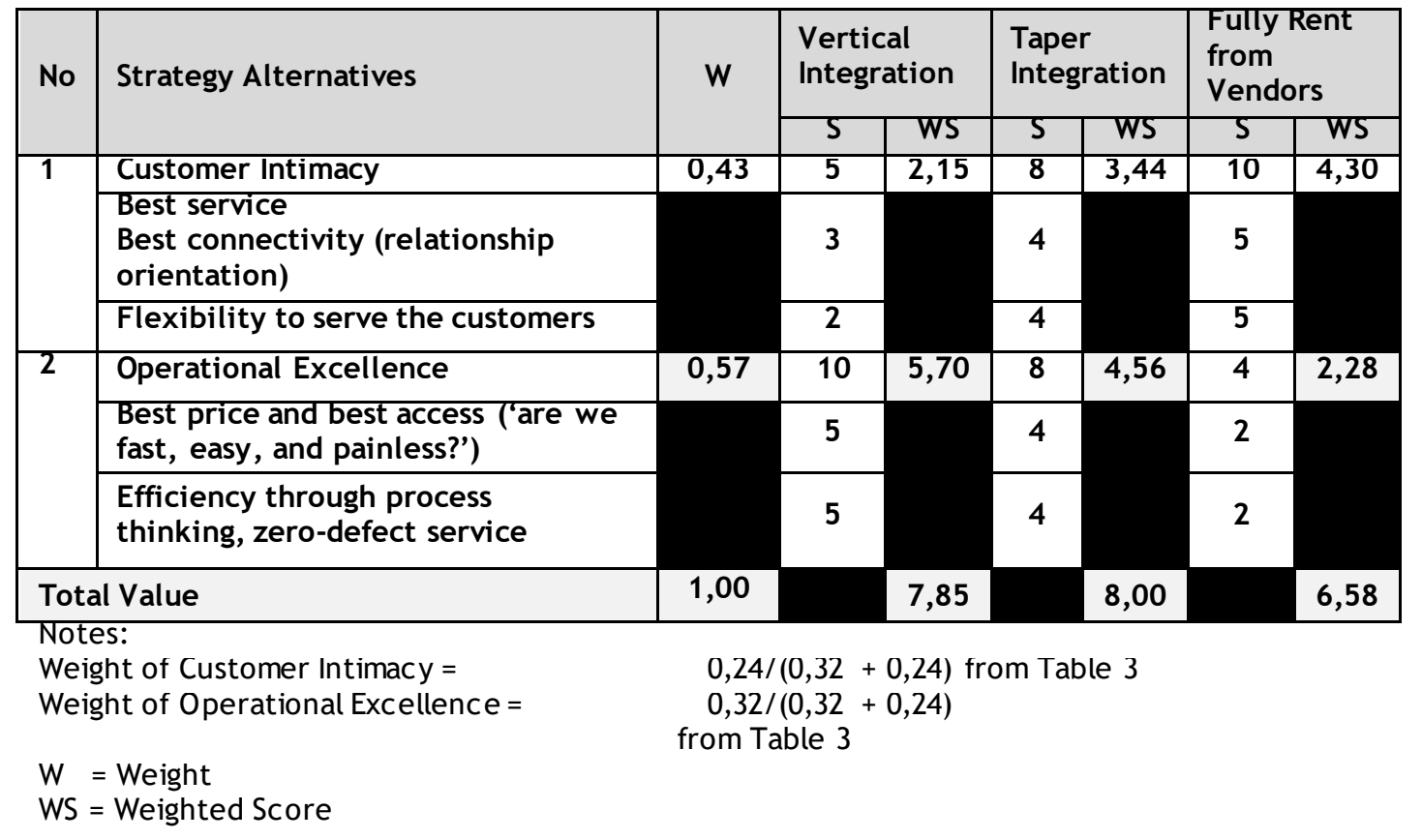

\section{b) Planning and control strategies for operations}

Operation planning and control that include supplier heavy equipment in taper integration can be done by integrating it with the company's heavy equipment and at the same time with the company's operating activities. The loading process can be done in an integrated manner to maximize operation efficiency and effectiveness together. This can be done because the company has high bargaining power and has completely understood the intricacies of this business.

\section{c) Business process management and strategies and implementation of standard operating procedures}

The Company also sets standard business processes for all activities induding those that are at suppliers so that the efficiency and effectiveness can become mutual benefit. In addition, overall management of employees' health and safety can also be implemented.

\section{Conclusion}

In accordance with the results of data collection, analysis and discussion is conduded as follows:

a) The Covid-19 pandemic is driving more threats than opportunities. Opportunities for XYZ include (1) there are still many customers power plant needs that can be served, (2) there are still many dredging and temporary jetty needs, (3) there is new ICT that can handle integrated coordination among operational region, (5) there is emergence of the needs for biomass transportation services as a new fuel. While the threats faced include (1) declining demand due to the COVID 19 Pandemic, (2) decreased use of coal for power plants (3) increasing potential for new competitors in the customer segment, (4) the length of the payment process from consumers, and (5) the impact of Covid-19 to increase the companies' operational cost.

b) For internal situation Covid-19 pandemic weakens the company because it increases operating costs. The overall company's strengths include (1) its experiences in the field of port services, 
(2) its strong asset management, (3) branch ownership spread across Indonesia, (4) its good track record, and (5) its strong network to customers (affiliated within the customers group) and it ownership of port business entity license (BUP). While the company's weaknesses include (1) its limited competent human resources, (2) its reliance on supplier infrastructure and equipment, (3) its incomplete standards of business process, application of risk management and implementation of integrated surveillance systems, (4) its limited ICT implementation.

c) To respond the above situation the strategic position of $X Y Z$ is a combination operational excellence and customer intimacy and implement defend strategy. In accordance with it the suitable XYZ's business strategy is to focus on the marine support service arena for customer group, using service differentiators that (1) meet global quality standards, (2) low prices, (3) hassle-free, (4) on-time delivery, (5) care for customers, and (6) responsive and proactive. XYZ controls its business processes with partners by interning taper vertical integration and compiling standards for operational excellence from this section. In addition, XYZ also conducts defensive strategies through working with its partners to create entry barriers both fix and mobile.

d) Operational strategies that need to be implemented to support XYZ's business strategy include taper integration, implementing integrated planning and control with suppliers, and setting and implementing standard and integrated business processes with suppliers.

\section{References}

1. ADB. (2020). Asean Development Bank Outlook (ADO) 2020 Supplement, July 2020. Mandaluyong City, 1550 Metro Manila, Philippines: Asian Development Bank.

2. Cardeal, N., \& Antonio, N. (2012). Valuable, rare, inimitabbe resources and organization (VRIO) resouces or valuable, rare, inimitable resources (VRI) capabilities: What leads to competitive advantage? African Journal of Business Management Vol. 6(37), 10159-10170.

3. Gupta, M., Czernik, A., \& Sharma, R. (2001). Operation Strategies of banks - using new technologies for competitive advantage. Technovation, 775-783.

4. Hembrick, D. C., \& Fredrickson, J. W. (2005). Are you sure you have a strategy ? The Academy of Management Executive.

5. International Monetary Fund. (2020). World Economic Outlook Update, June 2020. International Monetary Fund.

6. Maylin-Aguilar, C., \& Montoro-Sanchez, A. (2020). The Industry Life Cycle in an Economic Downturn: Lessons from Firm's Behavior in Spain, 2007-2012. Journal of Business Cycle Research.

7. Porter, M. (1985). Competitive Advantage, Creating and Sustaining Superior Performance. New York: The Free Press.

8. Sjödin, S., Wilder-Smith, A., Osm, S., Farooq, Z., \& Rocklöv, J. (2020). Only strict quarantine measures can curb the coronavirus disease (COVID-19) outbreak in Italy, 2020. Rapid communication, 1-6.

9. Treacy, M., \& Fred, W. (1996). The Discipline of Market Leaders - Choose Your Customers, Narrow Your Focus, Dominate Your Market. Canada.

10. Vasconcellos E SA, J. (2005). Strategy Moves - 14 complete attack and defense strategics for competitive advantage. Great Britain: Pearson Education Limited.

11. Verweire, K. (2018). The Challenges of Implementing Strategy - Advances in Project Management. PM World Journal Issue V - May 2018, 1-12. 